\title{
Preparedness and Practice Management Skills of Graduating Dental Students Entering the Work Force
}

\author{
Jane Manakil, Selwa Rihani, and Roy George \\ School of Dentistry and Oral Health, Griffith University, Gold Coast Campus, Parklands, Southport, QLD 4215, Australia \\ Correspondence should be addressed to Roy George; drroygeorge@gmail.com
}

Received 30 July 2014; Revised 6 November 2014; Accepted 24 November 2014

Academic Editor: Connie Wiskin

Copyright (C) 2015 Jane Manakil et al. This is an open access article distributed under the Creative Commons Attribution License, which permits unrestricted use, distribution, and reproduction in any medium, provided the original work is properly cited.

\begin{abstract}
Dental education aims to produce competent graduates with the ability to provide quality care to the patients and facilitate the smooth integration into professional practice. The objective of this study was to explore the overall preparedness of graduands for integrating into professional practice. The survey was tested for reliability and analysed the career paths, learning preferences, overall knowledge, and confidence amongst graduating dentists in integrating and managing a dental practice on graduation. Sixty-nine students (89.6\%) in age group of 20-50 years participated in the study. Students indicated a high level of confidence in their skills and ability to work in a team in a practice or collaboratively with other colleagues and specialists but expressed some reservation on their practice management skills (73.1\%). Challenges in gaining employment and pressures to repay educational debts are amongst the reasons for graduands preferring a paid job immediately on graduation regardless of demographics. Students indicated that an increase in speciality training and clinical/outreach placements could enhance employability. This study explores the students' perception of their confidences, knowledge, learning preferences, and practice management skills as a method of evaluating their preparedness to practice on graduation and provides a base line for curriculum structuring to prepare graduands to enter the competitive dental work force.
\end{abstract}

\section{Introduction}

The dental committee on the future of dental education had highlighted the need for careful recruitment and continued development of students and faculty as essential to the educational changes for future [1]. In Australia, to qualify as a dental practitioner, a student must complete the required academic and clinical training in an accredited educational environment for 5 years [2]. To embark on a career as a practitioner, graduating students are expected to be competent in providing quality holistic patient care and should also be prepared to adapt to needs of the society and be competent in the practice management. The present study seeks information across a broad range of areas, impacting the graduating students and concerning factors such as financial support during education, perceived confidence in skills, knowledge, career paths, learning preferences, and preparedness, along with practice management skills and employability.
Educational principles of the dental schools should facilitate the student's primary objective of integration into dental practice, while ensuring that students gain essential competency in providing quality holistic patient care $[3,4]$. The Association for Dental Education in Europe and the American Dental Association recommended that curriculum restructuring should focus on evidence based patient care as the fundamental part of the clinical education, along with highlighting the need for teamwork, practice management, and knowledge of information technology [4-6].

Henzi et al. [7] using student perspective project (SPP) and curriculum SWOT analysis (SWOT: curriculum strengths, weaknesses, opportunities for improvement, and threats to program quality) reported that majority of students desired a curriculum with a focus on developing clinical experience in clinical technique and technology [7]. It is also reported that students perceived that their integration into general dental practice could be better facilitated by more 
time in a clinical environment and more knowledge into practice management [7-9].

This study explored the confidence, fiscal status, career paths, learning preferences, and overall knowledge amongst graduating dentists in integrating into the mainstream dental work force. Study also considered the self-perceived knowledge in establishing and managing an independent practice.

\section{Materials and Methods}

The Human Ethics Committee of Griffith University, Australia, approved this research. The present survey questionnaire was a modification of work done by Manakil and George [9] and was designed to investigate the confidence, fiscal status, learning preferences, career paths, overall knowledge, and the integration or managing of the dental practice amongst graduating dentists. The graduating students from the final year of the Graduate Dental Science Program at the School of Dentistry and Oral Health, Griffith University, Gold Coast, Australia, were requested to participate in the survey. The survey was confidential and was distributed through a third party, to maintain anonymity. The questionnaires were divided into five parts: the first part of the questionnaire collected personal data such as age, gender, fiscal status, and income support options of students during the program.

The second part of the study evaluated the self-perceived confidence in skills obtained over the length of the dental educational programme. The responses were measured on a five-point Likert scale with " 1 " being high confidence and " 5 " being low confidence. This part looked at perceived confidence in operative skills, integrating into dental practice, patient management skills, and interpersonal skills. In Australia, as there is no residency program after the completion of five-year full time dentistry program, the graduands can either start their own practice or seek employment immediately on graduation. So these senior students were also asked about their impression of mentoring required in the early phase of their career as a general dental practitioner.

The third part of the survey analysed the student demographic employment preferences such as (1) private or public sector jobs, (2) rural or city based practice, (3) preferred speciality areas to practice, and (4) preference for establishing an independent practice. This part also looked at students current job applications.

The fourth part of the study assessed the student's perception and proficiency in managing an independent practice. Study evaluated the students' knowledge of the cost of Australian Dental Council registration, indemnity insurance, and the AHPRA's (Australian Health Practitioner Regulation Agency) mandatory requirements to maintain registration. The survey further tested students perceptions of their rights and responsibilities as a practitioner and importance of team work and their perceived knowledge on cost of materials and cost of running an independent practice on a Likert scale (" 1 " being very good and " 5 ” very poor).

To understand student's knowledge of principal cost and working cost of a practice, they were asked to estimate these costs (e.g., overall cost of practice, staff and management, advertisements, dental consumables, and equipment's
TABLE 1: Graduating student's fiscal status.

\begin{tabular}{lc}
\hline Financial options & $\begin{array}{c}\text { Valid percentage } \\
\text { of students } \\
(n=69)\end{array}$ \\
\hline Worked less than 24 hours & $26.9 \%$ \\
Worked more than 24 hours & $7.5 \%$ \\
Support from family \& worked & $22.4 \%$ \\
Support from HECS \& PELS \& worked & $43.4 \%$ \\
\hline
\end{tabular}

and infrastructure maintenance: electricity, water, council charges, etc.). The students' knowledge was analysed based on the financial costing of practice set-up put forward by National Australian Bank Health (NAB Health) in collaboration with MEDFIN and HICAPS. The average cost of setting up a practice with running cost in first year in Australia is estimated to be approximately AUD 200-250,000.

The fifth part of the study examined information on the learning preferences. Their interest in an additional year of internship (paid or unpaid) and topics that they perceived should have been included into the curriculum as a method of improving their employability and integration into the evolving work environment.

The completed questionnaires were entered into a spread sheet, the responses were evaluated using the descriptive statistics to estimate the frequency, and the items were correlated. The significance of the data and differences in selfperceived knowledge between men and women were tested using Mann-Whitney $U$ test. Cronbach's alpha was utilised to test internal consistencies within the questionnaire. The answer to the open-ended question about the preferred educational experience and suggestions were transcribed, and common themes were identified and grouped as the percentage frequency. The aim of these questions was to explore the insight on the curriculum from the perspective of a graduating student.

\section{Results}

The response rate for this study was $89.6 \%$ (69 students), amongst which 68 students provided personal information. The majority of respondents $(72.5 \%)$ were in the age group of 20-24 years, with females forming the majority $(60.3 \%)$. Approximately half of the participants (43.4\%) were dependent on HECS-HELP (Higher Education Contributions Scheme-Higher Education Loan Scheme) or similar loan to support their study and living expenses along with other incomes, while $22.4 \%$ of students were supported by family. To further support their university income, $26.9 \%$ of the students worked 24 hours/week or less, while a small minority worked over 24 hours a week (Table 1). It should be noted that the dental curriculum at the school provides clinical and lab sessions from 8 am to $7 \mathrm{pm}$ for $3 \mathrm{rd}$, 4 th, and 5 th year students. This flexibility allows students to work and support themselves without compromising their training.

In Part 2 of this study, majority of respondents (60.8\%) indicated that they were confident that their operative skills would allow for a smooth integration into general dental 
TABLE 2: Graduating student's confidence in smooth integration into general practice (1: Very high, 2: High; 3: Neutral; 4: Low; 5: Very low).

\begin{tabular}{|c|c|c|c|c|c|}
\hline Themes & 1 & 2 & 3 & 4 & 5 \\
\hline How confident are you in the skills attained to integrate into general practice? & $1.4 \%$ & $59.4 \%$ & $20.3 \%$ & $15.9 \%$ & $2.9 \%$ \\
\hline Is it important to have a mentor during your first few years in practice? & $37.7 \%$ & $31.9 \%$ & $7.2 \%$ & $10.1 \%$ & $13.0 \%$ \\
\hline How confident are you with your patient management skills? & $21.7 \%$ & $46.4 \%$ & $8.7 \%$ & $15.9 \%$ & $7.2 \%$ \\
\hline How confident are you in your interpersonal skills (staff)? & $37.7 \%$ & $31.9 \%$ & $7.2 \%$ & $10.1 \%$ & $13.0 \%$ \\
\hline How confident are you in your leadership skills? & $14.7 \%$ & $48.5 \%$ & $16.2 \%$ & $16.2 \%$ & $4.4 \%$ \\
\hline
\end{tabular}

TABLE 3: Graduating student's immediate plans after graduation.

\begin{tabular}{|c|c|c|c|}
\hline What sort of practice do you visualise once you graduate? & $\begin{array}{c}\text { Partnership } \\
5.9 \%\end{array}$ & $\begin{array}{c}\text { Employee } \\
91.2 \%\end{array}$ & $\begin{array}{l}\text { Sole } \\
2.9 \%\end{array}$ \\
\hline When will you consider opening an independent practice? & $\begin{array}{c}\text { Immediately } \\
0 \% \\
\end{array}$ & $\begin{array}{c}\text { After few years } \\
72 \% \\
\end{array}$ & $\begin{array}{c}\text { Not inclined } \\
28 \% \\
\end{array}$ \\
\hline If you had a choice, you would work in... & $\begin{array}{c}\text { City practice } \\
54.4 \%\end{array}$ & $\begin{array}{c}\text { Rural practice } \\
14.7 \% \\
\end{array}$ & $\begin{array}{c}\text { No preference } \\
30.9 \%\end{array}$ \\
\hline Where are you looking to gain employment? & $\begin{array}{c}\text { City practice } \\
53.7 \%\end{array}$ & $\begin{array}{c}\text { Rural practice } \\
19.4 \% \\
\end{array}$ & $\begin{array}{c}\text { No preference } \\
26.9 \% \\
\end{array}$ \\
\hline Where do you consider your strongest experience is in? & $\begin{array}{c}\text { Periodontics } \\
15.1 \%\end{array}$ & $\begin{array}{c}\text { Restorative dentistry } \\
80.3 \%\end{array}$ & $\begin{array}{c}\text { Prosthodontics } \\
6 \%\end{array}$ \\
\hline
\end{tabular}

practice immediately following graduation. Interestingly, we noted that the confidence level was higher for the 30-50 years' age group, $85.7 \%(n=8)$, in comparison with $20-24$ age groups, $64 \%(n=50)$, and $25-29$ age group (36.4\%). Further, male students $(77.8 \%)$ expressed a statistically significant level $(P=0.011)$ of confidence than their female $(51 \%)$ counterparts in their operative skills and ability to integrate into a private practice setting (Table 2). The present study did not look at the grade level of skill confidence within each discipline.

The study showed that there was a general consensus (98.5\%) on the importance of teamwork and leadership within a practice, as essential for a successful practice. The majority of students $(78.8 \%)$ perceived that they would be confident to work as a team and understood the importance of interprofessional collaboration (76.1\%) (Table 2).

Mentoring following graduation was considered important $(72.4 \%)$, with no statistically significant difference amongst male and female participants. A large number of the participants were confident in their patient management skills (68.1\%), interpersonal skills (69.6\%), and leadership skills (63.2\%). Cronbach's alpha was 0.855 in this category, suggesting a high internal consistency (Table 2).

When looking at career options, $91.2 \%$ of the respondents indicated that they would seek immediate employment, rather than starting their own practice. There were no differences amongst males or females in contemplating an independent private practice after a period of experience in the industry, with $72 \%$ of the participants indicating a preference to start their own practice. Questions of job preference indicated that $54.4 \%$ of students were keen on city practice and $14.7 \%$ rural practice and $30.9 \%$ had no specific preferences. There was no significant statistical difference among males (48.1\%) and females (58.5\%) on their preference for city practice. When quizzed about actual applications made, $53.7 \%$ indicated that they had applied for city based practices and $19.4 \%$ for a rural practice while $22.4 \%$ had applied for both rural and city practices (Table 3 ). Cronbach's alpha (0.682) indicated a good reliability between job preferences and application for a job. When looking at preferences for the type of employment, $68.2 \%$ showed preference to be employed in a private practice and $23.2 \%$ preferred government employment. Only a limited number of graduates were ready to consider university teaching, research, or a career in defence.

Part 4 of this study looked at student's perceived knowledge of the cost of running a practice, professional registration fee, cost of indemnity insurance, and maintenance of memberships/educational needs. Students indicated good awareness of Australian Dental Council registration, financial cost $(68.2 \%)$, requirements $(84.8 \%)$, cost of indemnity insurance $(43.5 \%)$, and continuing educational requirement (74.2\%). The Australian Health Practitioner Regulation Agency (AHPRA) web site was the primary source for this information (71.2\%) (Table 4).

The awareness of the cost of establishing and owning a practice was mixed with $35.8 \%$ indicating a cost in the range of AUD 200-250k and 31.3\% above AUD 500k. The yearly cost of running a practice was perceived by students $(32.3 \%)$ to be in the range of AUD 50k-100k and $30.8 \%$ indicated a cost of AUD 100k-150k. Staffing was perceived to be the primary cost $(44.9 \%)$ followed by council charges, cost of electricity, and maintaining the infrastructure of the practice (22.4\%) (Table 4). 
TABLE 4: Knowledge on owning and running an independent dental practice.

\begin{tabular}{|c|c|c|c|c|c|}
\hline $\begin{array}{l}\text { What is your knowledge on your rights and } \\
\text { responsibilities as a practitioner? }\end{array}$ & $\begin{array}{l}\text { Very good } \\
68.2 \%\end{array}$ & $\begin{array}{l}\text { Good } \\
24.2 \%\end{array}$ & $\begin{array}{c}\text { Neither good/poor } \\
6.1 \%\end{array}$ & $\begin{array}{l}\text { Poor } \\
1.5 \%\end{array}$ & $\begin{array}{l}\text { Very poor } \\
\quad 0 \%\end{array}$ \\
\hline $\begin{array}{l}\text { What is your knowledge on practice management } \\
\text { and finance? }\end{array}$ & $\begin{array}{l}\text { Very Good } \\
1.5 \%\end{array}$ & $\begin{array}{l}\text { Good } \\
26.9 \%\end{array}$ & $\begin{array}{c}\text { Neutral } \\
46.3 \%\end{array}$ & $\begin{array}{l}\text { Poor } \\
17.9 \%\end{array}$ & $\begin{array}{l}\text { Very poor } \\
7.5 \%\end{array}$ \\
\hline Cost of material and equipment & $\begin{array}{c}10 \mathrm{k}-50 \mathrm{k} \\
13.8 \%\end{array}$ & $\begin{array}{l}50 \mathrm{k}-100 \mathrm{k} \\
32.3 \%\end{array}$ & $\begin{array}{c}100 \mathrm{k}-150 \mathrm{k} \\
30.8 \%\end{array}$ & $\begin{array}{l}150-200 \mathrm{k} \\
12.3 \%\end{array}$ & $\begin{array}{c}200 \mathrm{k}-250 \mathrm{k} \\
10.8 \%\end{array}$ \\
\hline Cost of establishing a practice & $\begin{array}{c}50 \mathrm{k}-100 \mathrm{k} \\
1.5 \%\end{array}$ & $\begin{array}{c}100 \mathrm{k}-150 \mathrm{k} \\
13.4 \%\end{array}$ & $\begin{array}{c}150-200 \mathrm{k} \\
17.9 \%\end{array}$ & $\begin{array}{c}200 \mathrm{k}-250 \mathrm{k} \\
35.8 \%\end{array}$ & $\begin{array}{l}\text { Above } 500 \mathrm{k} \\
\quad 31.3 \%\end{array}$ \\
\hline
\end{tabular}

TABLE 5: Graduating student's learning preferences.

\begin{tabular}{|c|c|c|c|c|}
\hline $\begin{array}{l}\text { Most productive practical learning } \\
\text { experience }\end{array}$ & $\begin{array}{l}\text { Clinics } \\
26.9 \%\end{array}$ & $\begin{array}{c}\text { Field/community clinics } \\
47.8 \%\end{array}$ & $\begin{array}{r}\text { Both } \\
17.9 \% \\
\end{array}$ & $\begin{array}{c}\text { Community more } \\
7.5 \% \\
\end{array}$ \\
\hline $\begin{array}{l}\text { Suggestion for a better practical learning } \\
\text { experience }\end{array}$ & $\begin{array}{c}\text { More clinics/practice } \\
37.8 \%\end{array}$ & $\begin{array}{c}\text { More specialist sessions } \\
18.2 \%\end{array}$ & $\begin{array}{l}\text { More didactic sessions } \\
6.1 \%\end{array}$ & $\begin{array}{l}\text { All of them } \\
37.9 \%\end{array}$ \\
\hline Additional year of internship & $\begin{array}{c}\text { Yes even if no pay } \\
11.1 \%\end{array}$ & $\begin{array}{c}\text { Yes with pay } \\
66.7 \% \\
\end{array}$ & $\begin{array}{l}\text { Yes with part-time pay } \\
9.5 \%\end{array}$ & $\begin{array}{c}\text { Not even with pay } \\
12.7 \% \\
\end{array}$ \\
\hline $\begin{array}{l}\text { Did your course experience prepare you } \\
\text { to manage patients from diverse } \\
\text { backgrounds? }\end{array}$ & $\begin{array}{l}\text { Fully } \\
26.9 \%\end{array}$ & $\begin{array}{l}\text { Partly } \\
64.2 \%\end{array}$ & $\begin{array}{l}\text { Minimally } \\
7.5 \%\end{array}$ & $\begin{array}{l}\text { None } \\
1.5 \%\end{array}$ \\
\hline I can work collaboratively in a group & $\begin{array}{l}\text { Fully agree } \\
76.1 \%\end{array}$ & $\begin{array}{c}\text { Partly agree } \\
19.4 \%\end{array}$ & $\begin{array}{c}\text { Agree with reservations } \\
4.5 \%\end{array}$ & $\begin{array}{c}\text { Strongly disagree } \\
0 \%\end{array}$ \\
\hline
\end{tabular}

Part 5 of the study focussed on the learning preferences and suggestions. The students $(47.8 \%)$ preferred community/outreach/rural clinical placements in contrast to respondents $(26.9 \%)$ who preferred in-house clinical experience. More than half of the graduating students (55.3\%) suggested an increase in clinical placements will add to their experience (Table 5).

Looking at their overall learning experience, students (50\%) indicated that a combination of clinical and didactic training will enhance overall development and preparedness to practice. Students $(87.3 \%)$ were keen to have a one-year residency program, added to the current 5 years of dentistry program; however, a significant $(P<0.001)$ number of respondents $(76.2 \%)$ would only consider it if it was a paid residency (Table 5).

In Australia, being a multicultural society, students are encouraged to be competent in working, with population from diverse backgrounds. The majority (91.1\%) of respondents indicated that they were fully or partially confident in their preparedness for managing patients from culturally diverse backgrounds.

The open-ended question explored the insight on the curriculum and suggestion of the graduating seniors, phrased as, "What additional learning experiences would you prefer as part of the curriculum that would enhance your employability?" The respondent's specified increased knowledge on practice management along with at least a limited training in speciality areas such as orthodontics and implant and laser dentistry would help enhance their employability.

\section{Discussion}

Graduating students are increasingly being challenged with rapid development in the field of dentistry; this makes it essential that graduating students are well prepared with not only essential knowledge and skills but also patient and practice management skills. This survey questionnaire was modified from an earlier study by Manakil and George [10] and included a broader range of topics such as the students financial support, their preferential career path following graduation, perceived knowledge, and limitations they have encountered.

The study explored the source of financial support during the period of student's dental education. The data showed that students obtained funding through a variety of sources such as financial scholarships, working hours outside the scheduled educational period, and also parents or relatives. The cost of professional dental education is a concern shared by most graduands [11-13] in Australia, with some students often opting for Higher Education Loan Program (HECS-HELP), while others opt for support from relatives or part-time work to fund their university education $[14,15]$. The survey reflected that the educational debt influenced the graduands need to seek employment and career choice, immediately on graduation, with little thought on geographical location. The above findings are supported by the British Dental Association survey which reported considerable financial support is required to finish a dental degree and there are a large number of students in debt by fifth year of the program [16]. 
The 2012 Australian dental work force survey (2014) reported a registered dentist population of 72.3/100,000 in major cities and $22.7 / 100,000$ in remote areas [17]. The increasing number of dental practitioners is leading to an increased pressure in gaining employment in major cities [18]. These findings are similar to those reported in British studies; with an increased concentration of dentists in the major cities, new graduates are finding it increasingly difficult to find employment in the cities $[19,20]$. Interestingly, if given a choice, $54.4 \%$ of the graduating students would prefer a city based practice (Table 3 ). This may be due to the proximity of families around urban areas and also cities are financially more productive.

As a long term career goal, graduands (72\%) hoped to own a practice after gaining some work experience. Owning a private practice is often projected as social symbol of success $[7,21,22]$. However, immediately on graduation, $91.2 \%$ of the graduands would like to be employed; this is reflected in the students $(69.6 \%)$ desire to have a mentor for the first few years of practice outside university environment. This desire for additional mentoring while being employed has been recognised by the Australian Department of Health, with the introduction of the Voluntary Dental Graduate Year Program (2011-12 and 2014-15). This program seeks to provide dental graduates with an opportunity to enhance practice experience and a supported transition to practice. Geography of practice preference showed city practice as the primary choice $(54.4 \%)$ with no significant difference among genders in their choice, while private practice employment was favoured by $68.2 \%$ of graduands.

The dental graduates not only are required to be proficient in the patient care but also have to be competent in business/practice management [10]. Houlberg [23] in his study reported that there is inadequate training in practice management and suggested that the future dental curriculum should address the practice management training as an important component in the curriculum [23, 24]. In the current study, graduating students (73.1\%) perceived that they had insufficient knowledge on the cost of business/practice management (administration, advertisements, dental consumables, cost of equipment's and infrastructure maintenance, overhead cost of equipment, materials, staffing, etc.) (Table 4). However, the students' assumption about staffing being of high cost in a practice was correct, although they were unsure in other areas of the practice financial expenses. The students' knowledge was analysed based on the financial costing of practice by National Australian Bank Health in collaboration with Medfin (St Leonards, NSW, Australia) and HICAPS (Health Claims and Payments Solution for Health, Carlton, VIC, Australia). The average cost of setting up a practice with running cost in first year was estimated to be approximately AUD 200250,000; this corresponds with $35.8 \%$ of student responses. The breakdown showed that nursing support, rental costs and on going equipment/laboratory cost each to be approximately AUD 45,000 to 50,000; this corresponds to $44.9 \%$ of student responses (Table 4). To assist students, in practice management, the Australian Health Practitioner Regulation
Agency (AHPRA) web site provides graduating students with some information on practice management skills. Practice management is considered as part of competency in 2011 ADEA report and further endorsed by student affidavit $[5,6]$. Hence the study supports the suggestions that to manage a successful practice the training in practice management should be considered as a module in the curriculum for the graduating students and should continue even following graduation [24-27]. Furthermore, as Australia is a multicultural society (Caucasians, Aboriginals, Asians, Indians, and Europeans), it is important that students are prepared to be more receptive of diverse cultures and beliefs. Duke et al. [28] argued that it is time to ensure practitioners in all health disciplines are culturally competent, thus ensuring culturally safe care to patients. The 5th year students at this dental school are provided remote or outreach placements for 12-18 weeks, where people of various ethnic backgrounds usually represent the patient population. Interestingly, $91.1 \%$ of students claimed to be fully or partially confident in their preparedness for managing patients from culturally diverse backgrounds (Table 5).

Majority of students perceived that a combination of inhouse clinical experience and community/rural placements could contribute to their work preparedness for the general dental practice. This came as no surprise as a number of studies across various faculties have indicated the benefits of hands-on experience enjoyed by students [22, 29-31]. The increased inclination for community placements may be due to increased independence in patient management when compared to the in-house clinical teaching environment where students were assessed at each phase of the patient management on a grading scale [10]. Graduands indicated that they felt comfortable with their basic operative skills; however they felt increasingly challenged when more complex speciality skills were required. This disciplinary ambiguity towards special skills was also reflected in the studies by Henzi et al. and Gerbert et al. [30, 32]. The open-ended questions were specific on these areas that will enrich the curriculum like more training on practice management, more insight into speciality training in orthodontics, implant dentistry, and laser dentistry. The students suggested that these modifications would enhance their employability and widen their career choice. There are various studies in regard to the concerns of graduating students with their clinical skills and knowledge in dental implant, orthodontics, and practice administration $[6,33]$.

\section{Conclusion}

This study showed that students were confident in clinical skills developed but were a bit sceptic about their knowledge on practice management. Students were also keen on increasing their scope of practice by learning additional speciality skills. Increasing employability of graduands is becoming a challenge in an ever increasing and competitive work market; hence curricula should consider integration of clinical skills and knowledge with practice management skills. 


\section{Appendix}

\section{Questionnaire on Self-Perceived Work Preparedness of the Dental Students 2012}

Part 1. Personal data

Gender

\author{
$\square$ Male \\ $\square$ Female
}

Age

$\square 20-24$

25-29

口 30-50

Financial support during the course

$\square$ Part-time work less than 24 hours

$\square$ Part-time work more than 24 hours

$\square$ Unemployed supported by family

$\square$ Dependent on HECS/PELS/other sources

Part 2. Confidence on smooth integration into general practice (1: Very high confidence; 2: High confidence; 3: Neutral; 4: Low confidence; 5: Very low confidence)

\section{Themes}

$\begin{array}{lllll}1 & 2 & 3 & 4 & 5\end{array}$

How confident are you in the skills attained to integrate into general practice?

Is it important to have a mentor during your first few years in practice?

How confident are you with your patient management skills?

How confident are you in your interpersonal skills (staff)?

How confident are you in your leadership skills?
Part 3. Perception on independent practice and employment

What sort of practice do you visualise once you graduate?

$$
\begin{aligned}
& \square \text { Partnership } \\
& \square \text { Employee }
\end{aligned}
$$

$\square$ Sole

When will you consider opening an independent practice?

$\square$ Immediately

$\square$ After few years

$\square$ Not inclined

If you had a choice, you would work in...

$\square$ City practice

$\square$ Rural practice

$\square$ No preference

Where are you looking to gain employment?

$$
\begin{aligned}
& \square \text { City practice } \\
& \square \text { Rural practice } \\
& \square \text { No preference }
\end{aligned}
$$

Preferred employment: preferences in the scale of 1 (most preferred) to 6 (least preferred)

\section{$\square$ Government}

$\square$ University and research

$\square$ Defence

$\square$ Private

$\square$ Management

$\square$ Others

Where do you consider your strongest experience is in?

$\square$ Periodontics

$\square$ Restorative dentistry

$\square$ Prosthodontics
Part 4. Questionnaire is to gauge your knowledge on owning and running an independent dental practice. 
In the following questionnaire please mark the correct answer.

\section{Section 1}

Themes

Cost of the national
dental registration

Cost of material and equipment

$\begin{array}{ll} & \text { Less than } \$ 500 \\ & \$ 1000-1500 \\ \text { Cost of indemnity } & \$ 1500-2000 \\ \text { insurance } & \$ 2000 \text { Above } \\ & \text { Vary based on practice }\end{array}$

Continuing dental education points required for the maintenance of the registration

What is your knowledge on practice management and finance?

Annually

Less than $\$ 500$

\$500-999

$\$ 1000-2000$

$\$ 3000-4000$

$\$ 4000$ Above

$10 \mathrm{k}-50 \mathrm{k}$

$50 \mathrm{k}-100 \mathrm{k}$

$100 \mathrm{k}-150 \mathrm{k}$

$150-200 \mathrm{k}$

200k-250k

Vary based on practice

0 points

60 points/1 year

60 points $/ 2$ years

60 points $/ 3$ years

100 points/3 years

Very good

Good

Neither good/poor

Poor

Very poor

Very good

What is your knowledge on your rights and responsibilities as a practitioner?

Good

Neither good/poor

Poor

Very poor

ADAQ website

Where do you find valid AHPRA website

information on the rights Lecture classes

and responsibilities of Ask the academic staff

practice?

From peers

Very important

How do you grade the importance of team work?
Important

Neutral

Not sure of the importance Not important
Section 2

Cost of establishing a practice

$50 \mathrm{k}-100 \mathrm{k}$

$100 \mathrm{k}-150 \mathrm{k}$

$150-200 \mathrm{k}$

200k-250k

Above 500k

Major cost in running a practice: (on a scale of 1 to 5, 1 being of lowest priority while 5 being the highest)
$\square$ Staffing and management
$\square$ Infrastructure (electricity, water bills, etc.)
$\square$ Advertising
$\square$ Dental consumables
$\square$ Equipment

Part 5. Learning preferences

Most productive practical learning experience
$\square$ Clinics
$\square$ Field/community clinics
$\square$ Both

$\square$ Community more

Suggestion for a better practical learning experience

$\square$ More clinics

$\square$ More specialist sessions

$\square$ More didactic sessions

$\square$ All of them

Additional year of internship
$\square$ Yes even if no pay
$\square$ Yes with pay
$\square$ Yes with part-time pay
$\square$ Not even with pay

Did your course experience prepare you to manage patients from diverse backgrounds?

$$
\begin{aligned}
& \square \text { Fully } \\
& \square \text { Partly } \\
& \square \text { Minimally } \\
& \square \text { None }
\end{aligned}
$$

I can work collaboratively in a group

$$
\begin{aligned}
& \square \text { Fully agree } \\
& \square \text { Partly agree } \\
& \square \text { Agree with reservations } \\
& \square \text { Strongly disagree }
\end{aligned}
$$

Any novel subject that should be part of the course in future 


\section{Conflict of Interests}

The authors declare that there is no conflict of interests regarding the publication of this paper.

\section{References}

[1] M. J. Field, Dental Education at the Crossroads: Challenges and Change, The National Academies Press, Washington, DC, USA, 1995.

[2] ADC, Professional Attributes and Competencies of the Newly Qualified Dentist; Accreditation of Education and Training Programs for Dentists and Assessment of International Dental Graduates for Practice in Australia, Australian Dental Council, Melbourne, Australia, 2010.

[3] M. Manogue and G. Brown, "Managing the curriculum-for a change," European Journal of Dental Education, vol. 11, no. 2, pp. 75-86, 2007.

[4] M. Manogue, J. Mcloughlin, C. Christersson et al., "Curriculum structure, content, learning and assessment in European undergraduate dental education-update 2010," European Journal of Dental Education, vol. 15, no. 3, pp. 133-141, 2011.

[5] ADEA, "ADEA competencies for the new general dentist: (as approved by the 2008 ADEA house of delegates)," Journal of Dental Education, vol. 75, no. 7, pp. 932-935, 2011.

[6] G. E. Garrison, E. Lucas-Perry, D. E. McAllister, E. Anderson, and R. W. Valachovic, "Annual ADEA survey of dental school seniors: 2013 graduating class," Journal of Dental Education, vol. 78, no. 8, pp. 1214-1236, 2014.

[7] D. Henzi, E. Davis, R. Jasinevicius, and W. Hendricson, "In the students' own words: what are the strengths and weaknesses of the dental school curriculum?" Journal of Dental Education, vol. 71, no. 5, pp. 632-645, 2007.

[8] S. Khatami, M. I. MacEntee, D. D. Pratt, and J. B. Collins, "Clinical reasoning in dentistry: a conceptual framework for dental education," Journal of Dental Education, vol. 76, no. 9, pp. 1116-1128, 2012.

[9] J. Manakil and R. George, "Reviewing competency in dental education," International Journal of Dental Clinics, vol. 3, no. 2, pp. 33-39, 2011.

[10] J. Manakil and R. George, "Self-perceived work preparedness of the graduating dental students," European Journal of Dental Education, vol. 17, no. 2, pp. 101-105, 2013.

[11] R. J. Murphy, S. A. Gray, G. Sterling, K. Reeves, and J. DuCette, "A comparative study of professional student stress," Journal of Dental Education, vol. 73, no. 3, pp. 328-337, 2009.

[12] A. Polychronopoulou and K. Divaris, "Dental students' perceived sources of stress: a multi-country study," Journal of Dental Education, vol. 73, no. 5, pp. 631-639, 2009.

[13] G. H. Westerman, T. G. Grandy, R. A. Ocanto, and C. G. Erskine, "Perceived sources of stress in the dental school environment," Journal of Dental Education, vol. 57, no. 3, pp. 225-231, 1993.

[14] Aussie Educator, A Total Education Page for Australia, D \& B Mann Webmasters, 2013.

[15] A Government, Study Assist. Australian Government Assistance for Financing Tertiary Study, Australian Government, 2012.

[16] British Dental Association, "Dental student debt," British Dental Journal, vol. 205, article 24, 2008.

[17] Australian Institute of Health and Welfare, Dental Workforce 2012, National Health Workforce Series no. 7, Cat. no. HWL 53, AIHW, Canberra, Australia, 2014.
[18] A. Refshauge and D. Kalisch, Dental Workforce Survey 2011, The Australian Institute of Health and Welfare, Canberra, Australia, 2013.

[19] J. Lewney, "Are these the good old days?" British Dental Journal, vol. 216, no. 5, pp. 221-222, 2014.

[20] L. Pacey, "Investigation: careers in dentistry: are there still options?” British Dental Journal, vol. 216, no. 5, pp. 212-213, 2014.

[21] M. Baharvand, E. J. Moghaddam, H. Pouretemad, and K. Alavi, "Attitudes of Iranian dental students toward their future careers: an exploratory study," Journal of Dental Education, vol. 75, no. 11, pp. 1489-1495, 2011.

[22] J. Gallagher, W. Clarke, and N. Wilson, "Understanding the motivation: a qualitative study of dental students' choice of professional career," European Journal of Dental Education, vol. 12, no. 2, pp. 89-98, 2008.

[23] B. J. Houlberg, "Dental residents' perceptions of practice and patient management training during postgraduate education," Journal of Dental Education, vol. 72, no. 6, pp. 643-652, 2008.

[24] M. Barber, R. Wiesen, S. Arnold, R. S. Taichman, and L. S. Taichman, "Perceptions of business skill development by graduates of the University of Michigan Dental School," Journal of Dental Education, vol. 75, no. 4, pp. 505-517, 2011.

[25] D. C. Holmes, A. M. Diaz-Arnold, and V. D. Williams, "Alumni self-perception of competence at time of dental school graduation," Journal of Dental Education, vol. 61, no. 6, pp. 465-472, 1997.

[26] N. A. Nadershahi and D. B. Nielsen, "Educating the practiceready dentist," Journal of the California Dental Association, vol. 33, no. 10, pp. 801-804, 2005.

[27] D. O. Willis, "Using competencies to improve dental practice management education," Journal of Dental Education, vol. 73, no. 10, pp. 1144-1152, 2009.

[28] J. Duke, M. Connor, and R. McEldowney, "Becoming a culturally competent health practioner in the delivery of culturally safe care: a process oriented approach," Journal of Cultural Diversity, vol. 16, no. 2, pp. 40-49, 2009.

[29] W. R. Cardall, R. C. Rowan, and C. Bay, "Dental education from the students' perspective: curriculum and climate," Journal of Dental Education, vol. 72, no. 5, pp. 600-609, 2008.

[30] D. Henzi, E. Davis, R. Jasinevicius, W. Hendricson, L. Cintron, and M. Isaacs, "Appraisal of the dental school learning environment: the students' view," Journal of Dental Education, vol. 69, no. 10, pp. 1137-1147, 2005.

[31] A. E. Kossioni, R. Varela, I. Ekonomu, G. Lyrakos, and I. D. K. Dimoliatis, "Students' perceptions of the educational environment in a Greek Dental School, as measured by DREEM," European Journal of Dental Education, vol. 16, no. 1, pp. e73-e78, 2012.

[32] B. Gerbert, V. Badner, B. Maguire, J. Martinoff, S. Wycoff, and W. Crawford, "Recent graduates' evaluation of their dental school education," Journal of Dental Education, vol. 51, no. 12, pp. 697700, 1987.

[33] R. G. Weaver, J. E. Chmar, N. K. Haden, and R. W. Valachovic, "Annual ADEA survey of dental school seniors: 2004 graduating class," Journal of Dental Education, vol. 69, no. 5, pp. 595-619, 2005. 

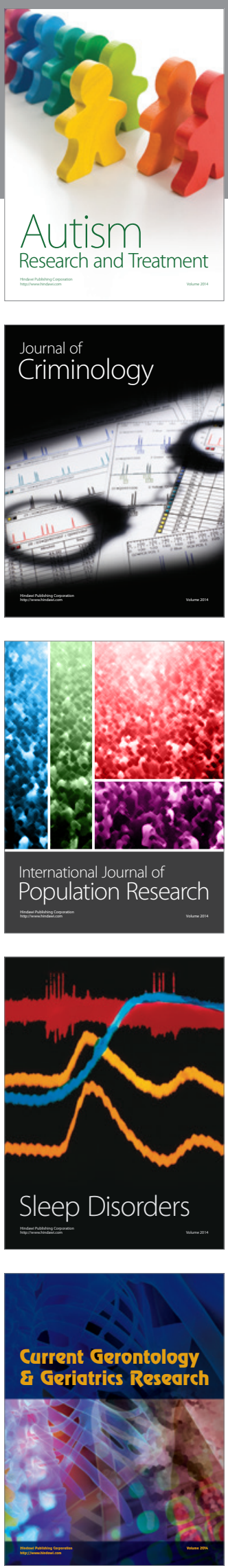
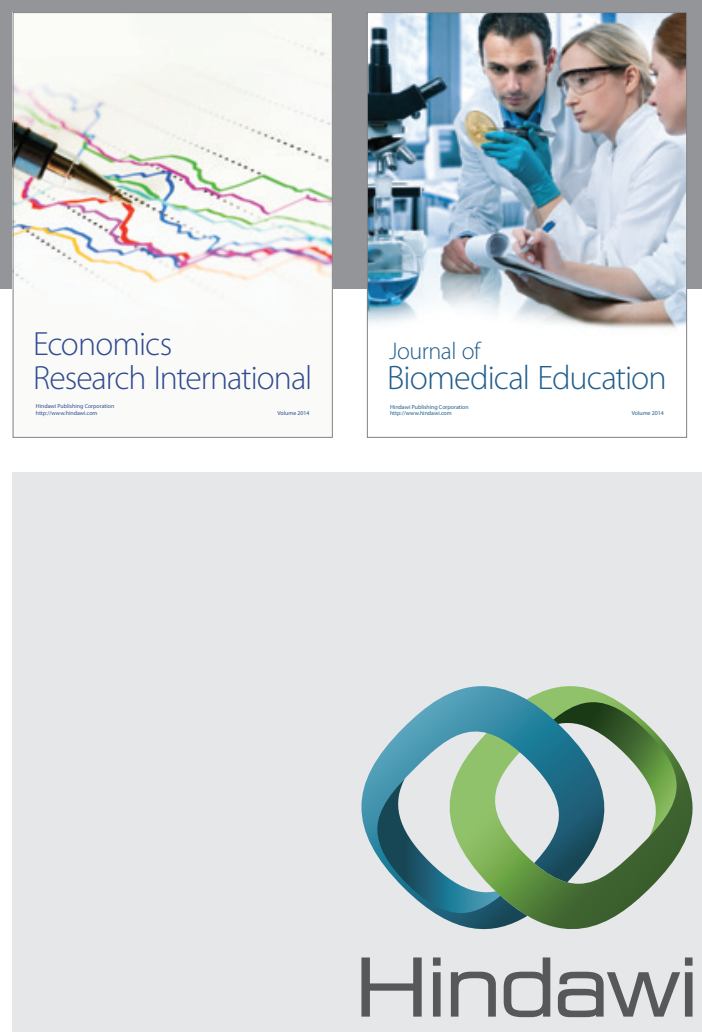

Submit your manuscripts at

http://www.hindawi.com
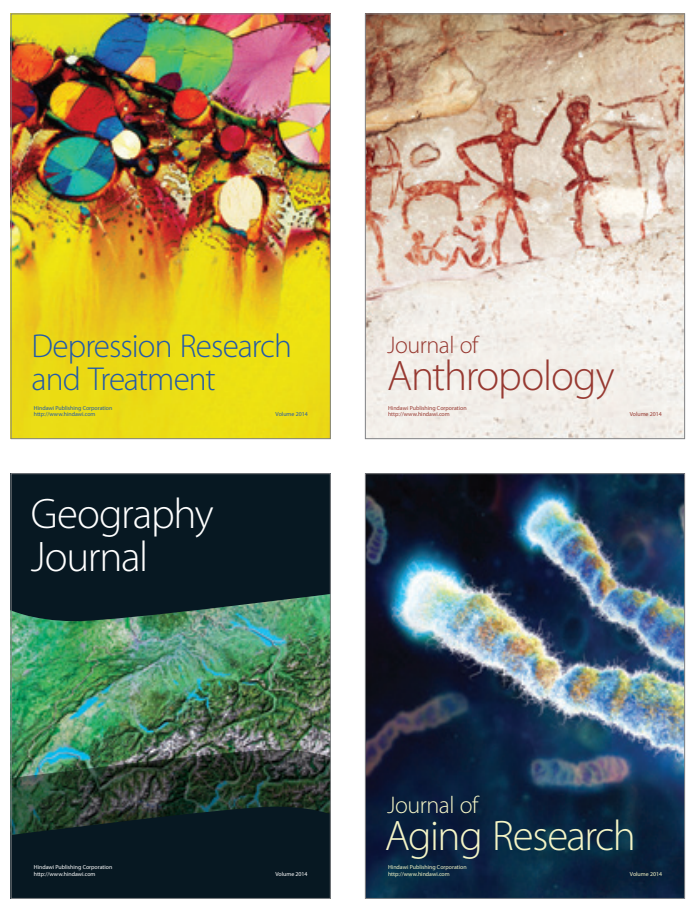
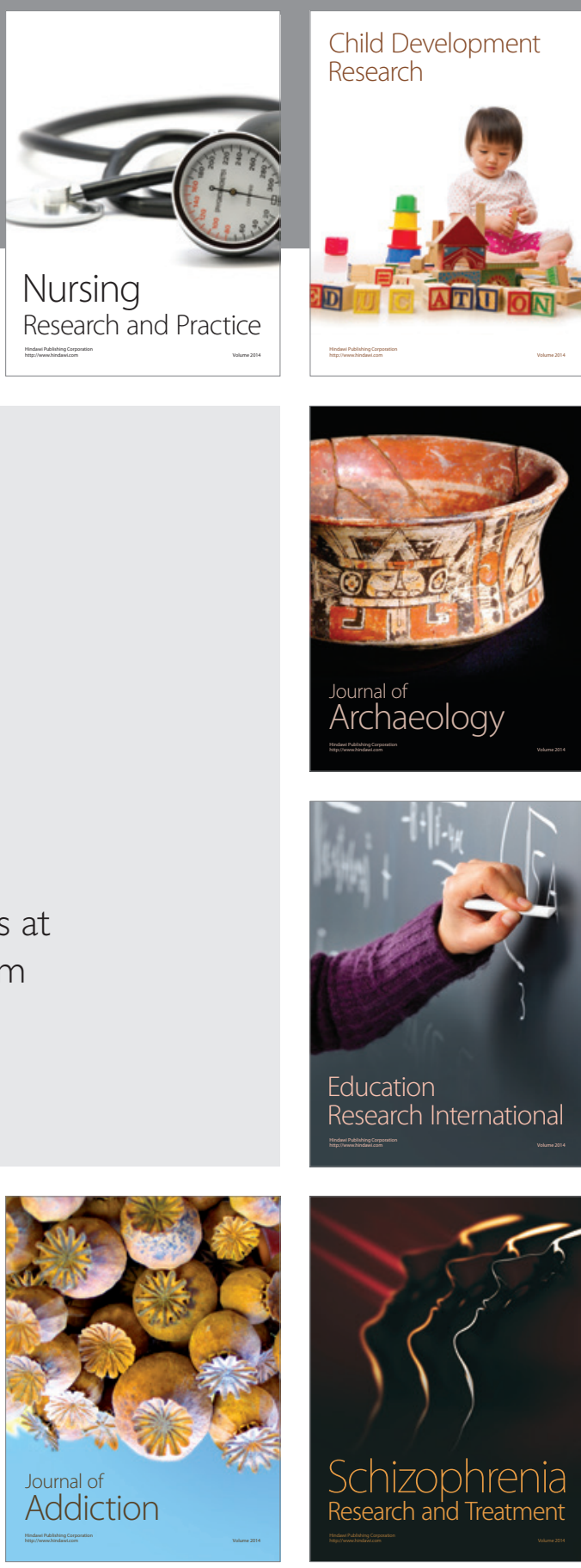

(D)
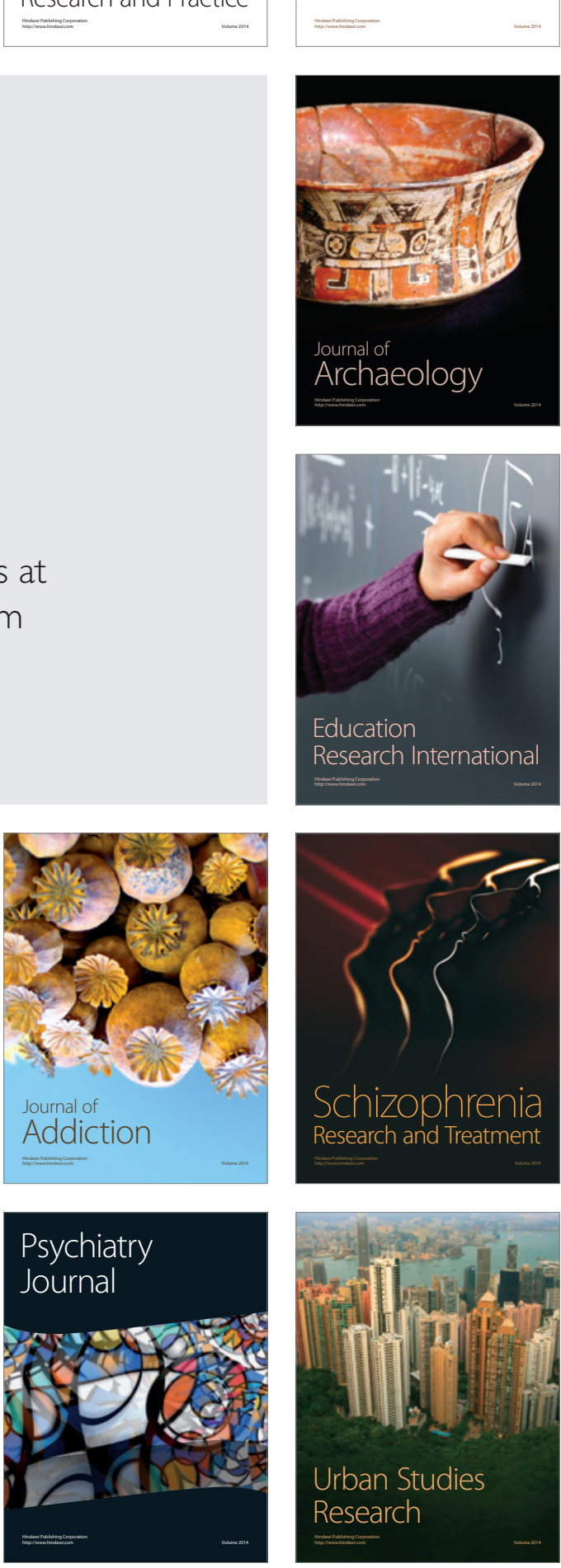